Portland State University

PDXScholar

\title{
Forest Management Scenarios in a Changing Climate: Trade-Offs Between Carbon, Timber, and Old Forest
}

\author{
Robert M. Scheller \\ Portland State University, rmschell@pdx.edu \\ Megan K. Creutzburg \\ Portland State University, mkc3@pdx.edu \\ Melissa S. Lucash \\ Portland State University, lucash@pdx.edu \\ Stephen D. LeDuc \\ United States Environmental Protection Agency \\ Mark G. Johnson \\ United States Environmental Protection Agency
}

Follow this and additional works at: https://pdxscholar.library.pdx.edu/esm_fac

Part of the Environmental Sciences Commons

Let us know how access to this document benefits you.

\section{Citation Details}

Creutzburg, M. K., Scheller, R. M., Lucash, M. S., LeDuc, S. D., \& Johnson, M. G. (2017). Forest management scenarios in a changing climate: trade-offs between carbon, timber, and old forest. Ecological Applications, 27(2), 503-518.

This Article is brought to you for free and open access. It has been accepted for inclusion in Environmental Science and Management Faculty Publications and Presentations by an authorized administrator of PDXScholar. Please contact us if we can make this document more accessible: pdxscholar@pdx.edu. 


\title{
Forest management scenarios in a changing climate: trade-offs between carbon, timber, and old forest
}

\author{
Megan K. Creutzburg,,${ }^{1,4}$ Robert M. Scheller, ${ }^{1}$ Melissa S. Lucash, ${ }^{1}$ \\ Stephen D. LeDuc, ${ }^{2}$ and Mark G. Johnson ${ }^{3}$ \\ ${ }^{1}$ Department of Environmental Science and Management, Portland State University, P.O. Box 751, Portland, Oregon 97207 USA \\ ${ }^{2}$ National Center for Environmental Assessment, U.S. Environmental Protection Agency, \\ 1200 Pennsylvania Avenue, $N W(8623$ P), Washington, D. C. 20460 USA \\ ${ }^{3}$ National Health and Environmental Effects Research Laboratory, U.S. Environmental \\ Protection Agency, 200 SW 35th Street, Corvallis, Oregon 97333 USA
}

\begin{abstract}
Balancing economic, ecological, and social values has long been a challenge in the forests of the Pacific Northwest, where conflict over timber harvest and old-growth habitat on public lands has been contentious for the past several decades. The Northwest Forest Plan, adopted two decades ago to guide management on federal lands, is currently being revised as the region searches for a balance between sustainable timber yields and habitat for sensitive species. In addition, climate change imposes a high degree of uncertainty on future forest productivity, sustainability of timber harvest, wildfire risk, and species habitat. We evaluated the long-term, landscape-scale trade-offs among carbon (C) storage, timber yield, and old forest habitat given projected climate change and shifts in forest management policy across 2.1 million hectares of forests in the Oregon Coast Range. Projections highlight the divergence between private and public lands under business-as-usual forest management, where private industrial forests are heavily harvested and many public (especially federal) lands increase $\mathrm{C}$ and old forest over time but provide little timber. Three alternative management scenarios altering the amount and type of timber harvest show widely varying levels of ecosystem $\mathrm{C}$ and old-forest habitat. On federal lands, ecological forestry practices also allowed a simultaneous increase in old forest and natural early-seral habitat. The ecosystem $\mathrm{C}$ implications of shifts away from current practices were large, with current practices retaining up to $105 \mathrm{Tg}$ more $\mathrm{C}$ than the alternative scenarios by the end of the century. Our results suggest climate change is likely to increase forest productivity by $30-41 \%$ and total ecosystem $C$ storage by $11-15 \%$ over the next century as warmer winter temperatures allow greater forest productivity in cooler months. These gains in C storage are unlikely to be offset by wildfire under climate change, due to the legacy of management and effective fire suppression. Our scenarios of future conditions can inform policy makers, land managers, and the public about the potential effects of land management alternatives, climate change, and the trade-offs that are inherent to management and policy in the region.
\end{abstract}

Key words: carbon; climate change; ecological forestry; forest ecology; LANDIS-II; landscape modeling; Northwest Forest Plan; Oregon Coast Range; retention harvest; wildfire.

\section{INTRODUCTION}

Forests provide multiple ecosystem services, including economic, ecological, and societal benefits. However, balancing these values presents a challenge, because of the potential trade-offs between services (Seidl et al. 2007, Phelps et al. 2012). For example, timber harvest may conflict with long-term carbon (C) storage (Thornley and Cannell 2000), and old-growth habitat must be weighed against habitat for early-successional species (Hansen et al. 1995, Spies et al. 2007a). Even in cases where the

Manuscript received 12 February 2016; revised 7 September 2016; accepted 12 September 2016. Corresponding Editor: Carolyn H. Sieg.

${ }^{4}$ Present address: Institute for Natural Resources, Oregon State University, P.O. Box 751, Portland, Oregon 97207 USA. Email: megan.creutzburg@oregonstate.edu type of trade-off is clear (e.g., harvesting vs. C storage), the magnitude of such a trade-off is likely not (e.g., increasing harvesting decreases ecosystem $\mathrm{C}$ by how much?). Balancing such trade-offs among ecosystem services can be particularly challenging in areas with a complex spatial configuration of ownerships, regulations, and forest management legacies (Swallow et al. 1997, Hein et al. 2006, Spies et al. 2007b). Policies and management choices may reflect the desired values for a given landowner, but developing policies that serve the interests of diverse stakeholders across a large landscape is difficult.

The Coast Range of Oregon is emblematic of these challenges, as it is a highly productive timber region, has been heavily harvested over the last century, and provides habitat for multiple sensitive species. The area also contains a heavily fragmented patchwork of federal, state, 
private, and tribal lands, each managed with different goals. Coast Range forests were intensively harvested from the 1890s through the 1990s, substantially reducing old-growth habitat (Kennedy and Spies 2004) and C storage (Smithwick et al. 2002), and increasing habitat fragmentation across the region (Butler et al. 2004). In response to the loss and fragmentation of old-growth forest, the Northwest Forest Plan (NWFP) was enacted in 1994 to protect areas with old-growth dependent species, such as the Northern Spotted Owl (Strix occidentalis) and Marbled Murrelet (Brachyramphus marmoratus) (Thomas et al. 2006). The NWFP substantially reduced harvesting on federal lands, increasing $\mathrm{C}$ storage and old forest habitat (Spies et al. 2007a, b), but also led to economic decline in rural, timber-dependent counties (Power 2006) and decreased natural early-seral habitat (Spies et al. 2007b). After 20 years under the NWFP, federal land managers are considering various options for future forest management policies to balance the ecological, economic and social integrity of the area.

Forest plans must also account for climate change, which is expected to modify the delivery of ecosystem services from forests worldwide. Climate change will alter physiological processes such as growth and respiration (Chmura et al. 2011, Lu et al. 2013) and shift suitable habitat for individual species, changing species distributions and community composition (Bachelet et al. 2001, Rehfeldt et al. 2006, Coops and Waring 2011). Forests store large amounts of C (Smithwick et al. 2002, Pan et al. 2011), and climate change may alter the ability of forests to continue to sequester C (Rogers et al. 2011, Loudermilk et al. 2013) and mitigate greenhouse gas emissions (Bonan 2008, D'Amato et al. 2011, Golden et al. 2011, McKinley et al. 2011). Climate change is also likely to affect disturbance regimes, with an expected increase in fire frequency, size and severity throughout the western United States (McKenzie et al. 2004, Westerling et al. 2006, Littell et al. 2010, Stavros et al. 2014). Climate change may also affect other disturbances such as insect outbreaks and disease (Kurz et al. 2008, Stone et al. 2008) and produce extreme weather events (Dale et al. 2001, Allen et al. 2010), increasing stress on forested ecosystems.

Policy makers, forest managers, and the general public will need to decide upon the proper balance between ecosystem services, and how to achieve this in the face of climate change. Here, to help inform these decisions, we used a simulation model to examine the trade-offs between several critical ecosystem services in the Oregon Coast Range. Specifically, we asked (1) What are the cumulative effects of varying management trajectories on ecosystem C storage (both above- and belowground), timber harvest, and old forest across the Coast Range? (2) What are the trade-offs between $\mathrm{C}$, timber, old forest and early-seral forest on federal lands under varying alternatives to the NWFP? And (3), how might climate change affect the ability of Coast Range forests to store $\mathrm{C}$ and provide ecosystem services? By answering these timely questions, we hope to better inform decisions as the NWFP is revised, while also illustrating these broadly applicable trade-offs relevant to many other forested systems.

\section{Methods}

\section{Study area}

The study area encompasses 2.1 million hectares of forested lands in the Coast Range and foothills of western Oregon (Fig. 1). The region contains a low mountain range, ranging in elevation from sea level to $1249 \mathrm{~m}$ and separating the Pacific Ocean from the Willamette Valley. The area is characterized by a temperate maritime climate with high annual precipitation (91 cm to more than $450 \mathrm{~cm}$ ), distributed primarily in the fall, winter, and spring months. Most precipitation falls as rain. Dominant forest species include Douglas-fir (Pseudotsuga menziesii (Mirb.) Franco), western hemlock (Tsuga heterophylla (Raf.)

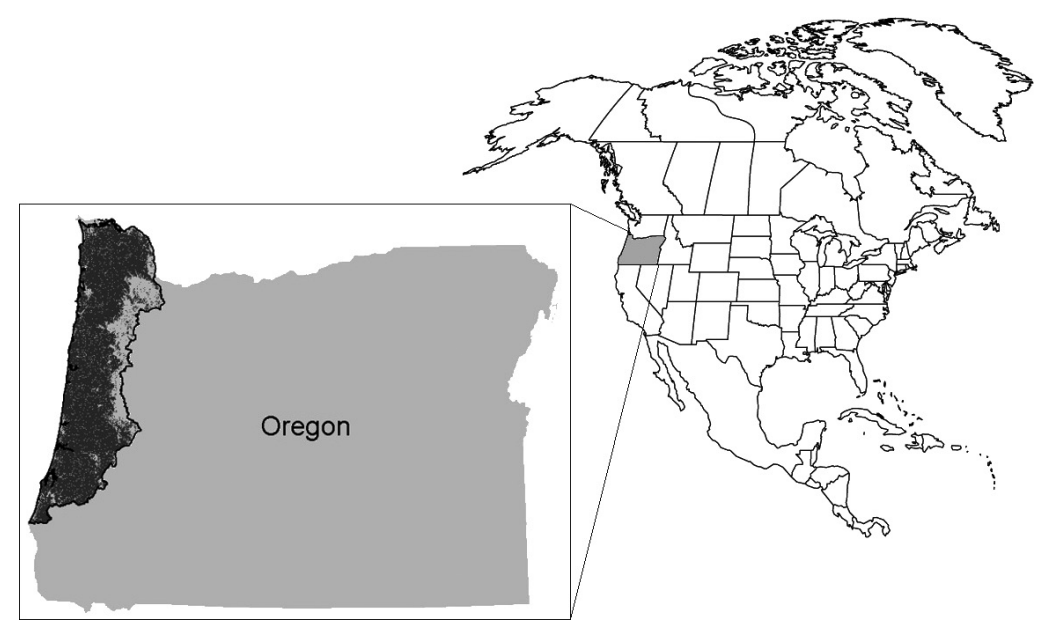

FIG. 1. The Oregon Coast Range study area occupies 2.1 million hectares of forests in western Oregon, USA (light shaded gray). In the inset map, the study area is outlined in black and forested pixels are shown in dark gray, and North America is shown for context. 
Sarg.), and Sitka spruce (Picea sitchensis (Bong.) Carr.). Land ownership consists of private lands (private industrial forests [PIF; 39\%] and private non-industrial forests [PNIF; $22 \%]$ ), federal lands (Bureau of Land Management [BLM; $14 \%$ ] and U.S. Forest Service [FS; 11\%]), state lands (13\%), and tribal lands $(<1 \%)$; together private lands cover a majority of the area in the Coast Range $(61 \%)$ and produce the greatest volume of harvested timber. Current timber harvest levels vary widely, with relatively short-rotation clear-cutting on PIF, a mixture of practices on PNIF and state lands, and limited harvest, generally restricted to thinning, on federal lands. As a result, stand composition and age are highly variable across the landscape. Wildfire is currently rare in the Coast Range, with an average of only 320 ha burned annually over the 44-year record, constituting $<0.1 \%$ of the landscape.

\section{Simulation modeling}

We used the LANDIS-II forest simulation model (Scheller et al. 2007) to project landscape-scale forest dynamics in the Coast Range. LANDIS-II simulates forest communities as tree species-age cohorts within gridded cells across the landscape, and simulates cohort regeneration, growth, and mortality based on life history and physiological attributes. Individual cohorts compete for resources (soil moisture, nitrogen, and growing space, a proxy for light) within each cell and tree species are dispersed across the landscape. Each cell is assigned to a soil type, climate, and disturbance regime, and disturbances and management activities are modeled as spatially explicit processes across the landscape. Simulations were run on a 4-ha grid ( $200 \mathrm{~m}$ cell side) over 90 years, from 2010 to 2100 .

Model extensions.-LANDIS-II operates as a core module interacting with extensions, each simulating succession, disturbances, or management. We used several extensions, including Century Succession (v4.0.1), Leaf Biomass Harvest (v2.1.1), Dynamic Fuels and Fire (v2.05), Leaf Biomass Fuels (v2.0), Leaf Biomass Output (v2.1), Cohort Statistics Output (v2.1.2), and Biomass by Age Output (v2.0.2), each described below.

The Century Succession extension (Scheller et al. 2011a) was derived from the Biomass Succession (Scheller and Mladenoff 2004) extension and the CENTURY model (Parton et al. 1983). It tracks multiple pools of live and dead tree $\mathrm{C}$ (including leaf, wood, fine root, coarse root, coarse woody debris, litter, and surface residue) and active, passive, and slow pools of soil organic matter. It operates on a monthly time step (summarized from daily input data) and incorporates temperature and precipitation data from historic records or models of future climate. Century Succession simulates growth and competition based on limitations from temperature, water, nitrogen, leaf area index, and growing space available to each species-age cohort. In Century Succession v 4.0.1, the same climate data stream is used to model all processes through a centralized climate library (Lucash and Scheller 2015). In this version, the soil water budget was modified to improve its representation of the amount of water available to trees.

The Leaf Biomass Harvest extension simulates a wide variety of harvest prescriptions by specifying the timing and amount of harvest removal. The extension allows thinning or complete removal (clearcutting) of each species-age cohort group, planting following harvest, and other prescriptions, with spatial placement dictated by maps of management areas and stands. Our simulations assumed that $80 \%$ of the aboveground woody biomass was merchantable and taken off site (Zhou and Hemstrom 2009), with the remaining $20 \%$ of woody material left as residue on site. The raw harvest output was reported in $\mathrm{Mg}$ biomass, and was converted to timber volume $\left(\mathrm{m}^{3} / \mathrm{ha}\right)$ using an average Douglas-fir oven-dry wood density of $400 \mathrm{~kg} / \mathrm{m}^{3}$ (Pong et al. 1986).

The Dynamic Fuels and Fire (DFF) extension simulates wildfire as a function of ignitions, fuels, topography, and fire weather (Sturtevant et al. 2009). Algorithms of fire ignition and initiation are based on Yang et al. (2004) and fire spread rates are dependent upon fuel type, weather, and topography, based on the Canadian Forest Fire Behavior Prediction System (CFFBPS; Forestry Canada Fire Danger Group 1992). The CFFBPS was used as a general framework for simulating fire but was entirely re-parameterized to reflect fuel types of the area (see Wildfire inputs). In the model, fire spreads across the landscape on a daily time step using the spread algorithms from Finney (2002). DFF was modified in this version to integrate climate data directly from the Century Succession extension through the LANDIS-II Climate Library (Lucash and Scheller 2015). The Leaf Biomass Fuels extension (Scheller et al. 2011c) uses aboveground live biomass of species-age cohorts to determine a fuel type for each cell at each time step, corresponding to fuel types in the Dynamic Fuels and Fire extension.

To summarize model outputs, we used the Leaf Biomass Output and Biomass-by-Age Output extensions to summarize changes in the biomass of each species. We also used the Cohort Statistics Output extension to calculate the maximum age for each cell, in order to estimate changes in the amount of old forest and early-seral forest.

Vegetation inputs. - We simulated 19 tree species, including the most common tree species in the Coast Range as well as less common species that may be expected to increase in abundance with climate change (Table S1). To create maps of initial forest composition, we used the gradient nearest neighbor (GNN) map for the Oregon Coast Range (map region 223) produced by the Landscape Ecology, Modeling, Mapping, and Analysis group for Northwest Forest Plan Effectiveness Monitoring (Ohmann and Gregory 2002). GNN maps use an imputation technique to assign forest inventory plots to a raster map. We obtained the supplemental TREE_LIVE database for the GNN map to summarize species-age 


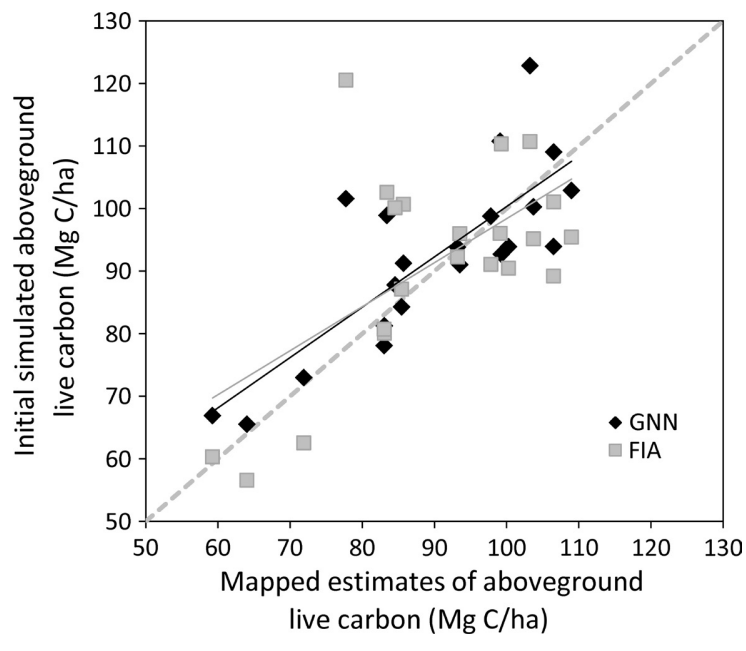

FIG. 2. Initial aboveground live $\mathrm{C}$ simulated in LANDIS-II compared to mapped $\mathrm{C}$ estimates from gradient nearest neighbor (GNN) and U.S. Forest Service forest inventory and analysis (FIA) maps. Each point represents a modeled ecoregion, comprising a unique combination of climate and soil properties (ecoregion descriptions are listed in Appendix S1). The 1:1 line is shown as a dashed gray line and regression lines are shown for GNN (black; $R^{2}=0.63$ ) and FIA (gray; $R^{2}=0.37$ ).

cohorts in each pixel at 10-yr age intervals. Parameters were derived from the literature where possible (Appendix S1), and the remaining parameters were calibrated to produce growth patterns consistent with the literature, as in Creutzburg et al. (2015). Initial simulated levels of aboveground $\mathrm{C}$ were calibrated to GNN and U.S. Forest Service Inventory and Analysis (FIA) maps of biomass ${ }^{5}$, using a factor of 0.47 to convert from biomass to $\mathrm{C}$ (Fig. 2).

Biophysical inputs.-LANDIS-II requires that the study area be divided into ecoregions, each assumed to have homogeneous climate and soils. In the Coast Range, we defined three climate regions and seven soil regions, for a total of 21 unique ecoregions. Average annual precipitation in the three climate regions was 91-171, 172-271, and $>272 \mathrm{~cm}$ for the low, medium, and high precipitation climate regions, respectively (Daly et al. 1997). Climate data were input as daily minimum temperature, maximum temperature, total precipitation, wind speed and wind direction, obtained from the U.S. Geological Survey (USGS) GeoData Portal as an area-weighted average for each climate region (data available online) ${ }^{6}$ Climate data were processed by the climate library of LANDIS-II, and used for both the Century succession and DFF extensions (also see Wildfire inputs). Soil regions were based on available water content from the SSURGO soil database (available online), ${ }^{7}$ broken into seven categories based on natural breaks. Percent clay, percent sand, field

\footnotetext{
${ }^{5} \mathrm{http}: / /$ data.fs.usda.gov/geodata/rastergateway/biomass/

${ }^{6} \mathrm{http}: / /$ cida.usgs.gov/gdp/

${ }^{7} \mathrm{http}: / /$ websoilsurvey.nrcs.usda.gov/
}

capacity, wilting point, drainage class, and soil $\mathrm{C}$ were taken from SSURGO as a weighted average to $1 \mathrm{~m}$ depth for each ecoregion using the Natural Resources Conservation Service soil data viewer, v. 6.1. Soil nitrogen was calculated from the SSURGO soil C data, assuming an average $\mathrm{C}: \mathrm{N}$ ratio of 17 (Perakis et al. 2011). Nitrogen inputs were assumed to come from wet and dry deposition, biological fixation in lichens, soil, and decaying logs (Sollins et al. 1980, Johnson et al. 1982, Fenn et al. 2003, Zhang et al. 2012), and fertilization in managed forests. Nitrogen inputs totaled roughly $14 \mathrm{~kg} \mathrm{~N} \cdot \mathrm{ha}^{-1} \cdot \mathrm{yr}^{-1}$. All parameters for the Century Succession extension are listed in Appendix S1.

Wildfire inputs and calibration.-Inputs to the fire and fuels extensions also included fire season, fire size or duration distributions, fuels properties by species and age, and others. DFF is both calibrated and emergent, relying on historical data to calibrate a distribution of fire durations under current climate and suppression levels, but allowing changes in fire weather index (FWI) and fuel moisture as future climate changes. We designated three fire regions in our landscape, which were identical to the precipitation regions (see Biophysical inputs). We also developed slope and azimuth maps using the Slope and Aspect tools, respectively, in ArcMap v 10.1. Daily weather data were integrated into the extension via the LANDIS-II Climate Library (Lucash and Scheller 2015). Based on the seasonal distribution of fires in the historical record, we assigned March-June as spring months, July-October as summer months, and November-December as fall months. No fires were allowed to occur in January or February. We used 12 fuel types from Syphard et al. (2011), grouping species-age cohorts by species composition (mixed conifer, pine, cedar/hemlock/sequoia, oak, and other deciduous) and age (generally $0-40,41-80$, and $81+\mathrm{yr}$ ). A prior sensitivity analysis of fire rotation period using similar fuel types indicated that the fire model is most sensitive to ignition rate, the relationship between fire weather and fire duration, and two fuel-specific parameters (Sturtevant et al. 2009). Data on fire size, date and location for all fires from 1967 to 2011 were obtained from the Oregon Department of Forestry, and were filtered to omit fires $<4$ ha (the size of one simulation cell). All fire and fuels parameters are documented in Appendix S1.

The effects of management on wildfire were explicitly and implicitly incorporated. Explicitly, fuel types changed due to any harvest activity or vegetation treatment and subsequent succession. Implicitly, we calibrated fire durations to approximate the frequency and size distribution (negative exponential) of fires in the 45-year record (Fig. 3) under contemporary climate (1950-2009) with current harvesting prescriptions and with current fire suppression levels. Due to the high precipitation in the region, active suppression, and long fire rotation, the historical fire size data do not capture large, infrequent fires outside the bounds of historic conditions. Nevertheless, changes to temperature and precipitation 


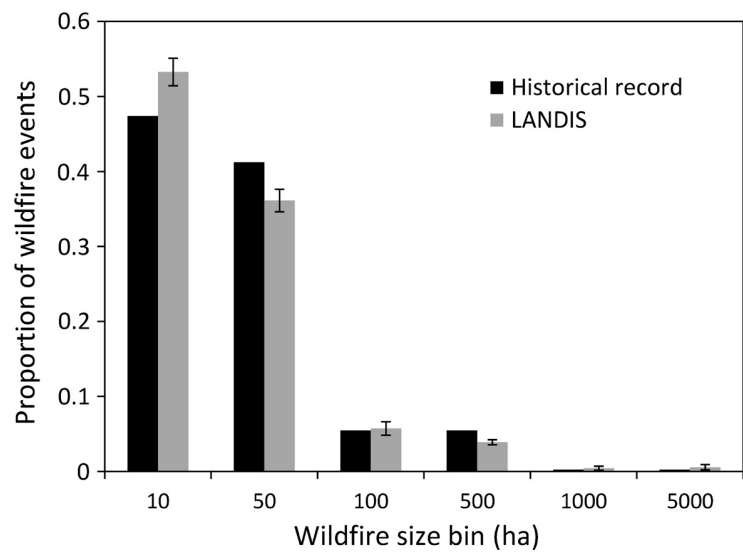

FIG. 3. Fire size distribution in the historical data record (1967-2011) and 10 replicate LANDIS-II simulations under contemporary climate (drawn from data in years 1950-2009; mean $\pm 1 \mathrm{SD})$.

can alter FWI, fire size, and severity under climate change. Fire severity is measured as an index ranging from 1 to 5 , with 1 being the least severe and 5 being the most severe (see Sturtevant et al. 2009 for more details).

Management inputs.-Two spatial layers are required for harvesting, a management area map and a stand map. The management area map designates major ownership types and land management allocation boundaries (Table 1) and the stand map delineates the boundaries where individual prescriptions can occur. The management area map was obtained from the Integrated Landscape Assessment Project $^{8}$ and modified in two ways (map available online). First, updated management maps for state lands were supplied by the Oregon Department of Forestry. Second, we added an allocation for PNIF reserve areas to account for a small proportion of PNIF lands that are not likely to be intensively harvested. These reserves encompassed the forested fragments along the eastern portion of the study area. Management allocations within an ownership were assigned an intensity level from no activity (level 1) to high-intensity management (level 4). We developed the stand map by classifying the current vegetation map into age groups, and iteratively filtering and cleaning boundaries in ArcGIS 10.1 (Esri, Redlands, California, USA) to group stands by age classes, remove very small stands and aggregate to observed stand sizes (Johnson et al. 1999, Briggs 2007). We intersected a hexagon layer with $1000-\mathrm{m}$ sides with this map to limit the maximum stand size where ages classes were similar across large areas. In the final map, stand sizes averaged 12 ha. For the ecological forestry scenario (see Scenarios: Management scenarios), we developed an alternative stand map using a similar approach but aggregated to larger stand sizes, averaging 68 ha.

\footnotetext{
${ }^{8} \mathrm{http}: / /$ westernlandscapesexplorer.info/AccessILAPData MapsModelsandAnalyses\#GIS
}

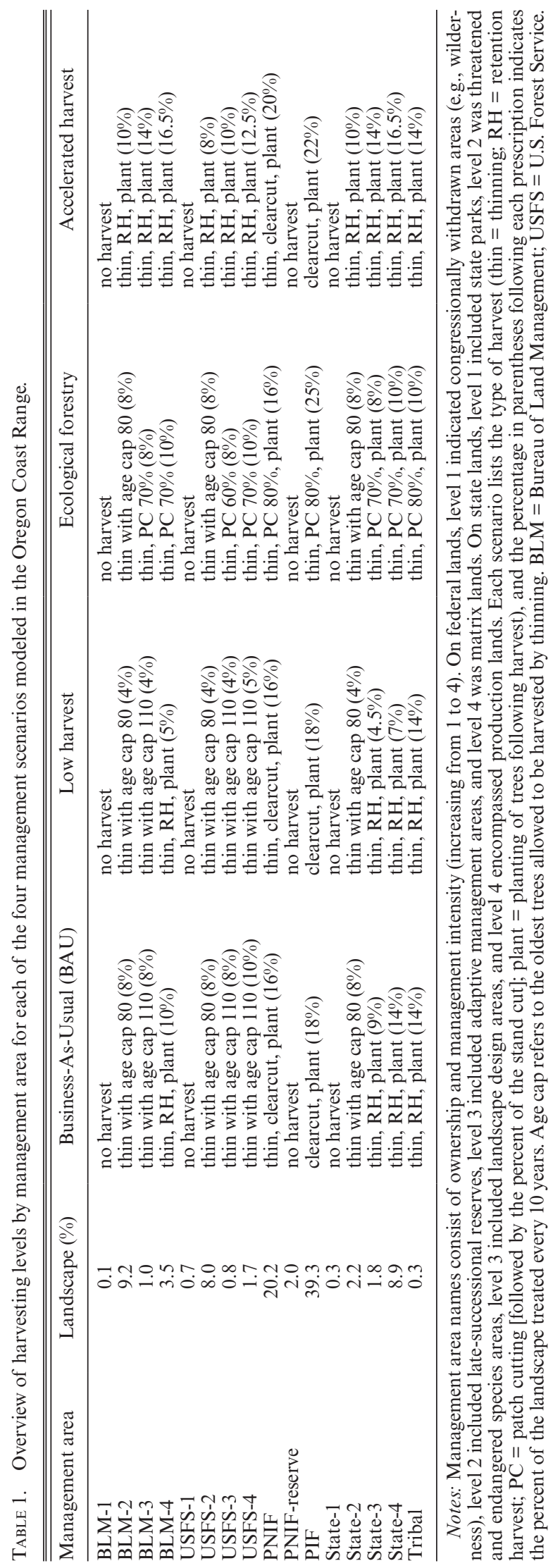




\section{Scenarios}

Management scenarios.-To develop a set of management scenarios, we held a stakeholder workshop in July 2014 in Corvallis, Oregon. We included as many interested stakeholders as possible, including representatives from the BLM, U.S. Forest Service, Environmental Protection Agency, Native American tribes, Oregon Department of Forestry, timber industry, environmental groups, and academia. Four scenarios were chosen for simulation: Business-As-Usual (BAU) management, Low Harvest, Accelerated Harvest, and Ecological Forestry. Each management scenario represented a broad policy trajectory regarded as generally plausible, and contained prescriptions specific to each ownership type and management intensity level. Management intensity was relative within each ownership (e.g., high management intensity was very different on federal vs. private lands; Table 1).

The BAU scenario simulated current harvest rates, including the implemented effects of the Northwest Forest Plan, based on literature (Johnson et al. 1999, Briggs 2007) and discussions with managers and experts in the region (Table 1). The BAU scenario reflects current practices, which are widely disparate among ownership types, with very little harvesting on federal lands, intermediate harvesting on state lands, and high levels of harvesting on private lands. In this scenario, timber production was maximized on private lands through clearcuts, harvest was mostly restricted to thinning on federal lands, and state lands allowed a mix of thinning and retention harvest. State lands are currently harvested more aggressively than federal lands, primarily using retention harvesting but maintaining wide riparian buffers. State lands, however, are still subject to restrictions in sensitive areas, and roughly $17 \%$ of state lands maintain high restrictions on harvest due to the presence of sensitive species. Clearcuts removed all cohorts within a stand, followed by replanting of Douglas-fir. Thinning treatments removed a percentage (typically 60\%) of younger tree cohorts, without removing older trees. Retention harvest removed younger cohorts and retained older cohorts, with percent removal and age restrictions variable across management areas. Retention harvest was followed by planting of Douglas-fir. Note that retention harvest was different than patch cutting, used in the Ecological Forestry scenario, and areas of retention harvest were not counted as old forest due to the harvest disturbance.

The Low Harvest management scenario contained the same prescriptions as BAU but harvested half the area on public (federal and state) lands, compared to BAU.

In the Ecological Forestry scenario, patch cutting was used to harvest larger areas at a lower intensity, with intact remnant patches remaining. In addition, some harvested areas were allowed to naturally recolonize, providing early-seral habitat currently uncommon in the Coast Range (Spies et al. 2007a). This scenario was informed by the work of Franklin and Johnson (Franklin et al. 2002, Franklin and Johnson 2012), which uses principles of ecosystem and disturbance ecology to guide restoration while providing increased timber supply. In this scenario, we increased stand sizes (see Management inputs) and used patch cutting within each stand to create a mosaic of cut and uncut patches without large clear-cuts (Table 1). Patch cutting removed a percentage of each stand in 4-ha blocks, resulting in a mosaic of small cuts and uncut forest. On federal lands, patches were not replanted, allowing early-seral communities to recolonize naturally. Similar treatments have been implemented in several BLM pilot projects in southwestern Oregon (Wheeler 2012).

The Accelerated Harvest scenario increased timber harvest rates substantially over current levels on most lands, while maintaining some of the protected old forest habitat on public lands. This scenario increased the percent area of clearcutting on private land, and increased the use of retention harvest over thinning on state and federal lands (Table 1). Retention harvest resulted in simulation cells with younger cohorts removed and older cohorts remaining; these areas did not count as old forest because they experienced a harvest event.

Climate scenarios.-Climate change projections were from the Bias Corrected Constructed Analogs V2 Daily Climate Projections dataset (Brekke et al. 2013) available on the GeoData Portal website. We chose five global circulation models (GCMs) to bracket the anticipated range of future climate projections in the region, including BNU-ESM (College of Global Change and Earth System Science, Beijing Normal University), MRI (Meteorological Research Institute), CanESM2 (Canadian Centre for Climate Modelling and Analysis), CCSM4 (National Center for Atmospheric Research) and NorESM (Norwegian Climate Centre) (Table 2). All GCMs were modeled under representative concentration pathway 8.5, representing high greenhouse gas forcing of the atmosphere. For future projections under contemporary climate (and model spin-up), we used daily Gridded Observed Meterological Data over the period 1950-2009 from the GeoData portal (Maurer et al. 2002).

TABLE 2. Temperature and precipitation under contemporary climate (1950-2009) and five models of projected climate change in the time period 2080-2100.

\begin{tabular}{lcc}
\hline \hline \multicolumn{1}{c}{ Climate scenario } & $\begin{array}{c}\text { Average annual } \\
\text { temperature } \\
\left({ }^{\circ} \mathrm{C}\right)\end{array}$ & $\begin{array}{c}\text { Total annual } \\
\text { precipitation } \\
(\mathrm{cm})\end{array}$ \\
\hline Contemporary (1950-2009) & 9.9 & 198 \\
Future BNU (2080-2100) & 15.1 & 208 \\
Future CanESM (2080-2100) & 15.1 & 191 \\
Future CCSM (2080-2100) & 14.8 & 227 \\
Future MRI (2080-2100) & 13.1 & 196 \\
Future NorESM (2080-2100) & 14.2 & 230 \\
\hline
\end{tabular}

Note: All climate change projections assume a high greenhouse gas forcing scenario (representative concentration pathway 8.5). 


\section{Running simulations}

The long duration of each simulation $(\sim 36 \mathrm{~h})$ limited the number of replicates, but scenarios were replicated where possible to account for stochastic variability in climate, wildfire and regeneration. Under the BAU harvest scenario, we ran 10 replicates each under of the climate scenarios (contemporary climate and each of the five GCMs). Management scenarios were replicated only once, as variability among model runs was minimal at a landscape scale (Duveneck et al. 2014). Old forest was defined as areas with the maximum cohort age $>200 \mathrm{yr}$ and undisturbed by harvesting during the simulation. Natural early-seral forest was defined as forest $<50 \mathrm{yr}$ old without planting of trees following harvest during the simulation, allowing natural regeneration. Natural regeneration could occur in any of the 19 simulated species, depending on their location, age and maturity of existing cohorts, shade tolerance, and dispersal distance.

\section{RESULTS}

\section{Cumulative impacts of management across the Coast Range landscape}

Across the whole Coast Range landscape, ecosystem C accumulated in both aboveground and belowground pools over the century under all management scenarios (Fig. 4a-c; note that detrital $\mathrm{C}$ pools are not shown separately but are included in total ecosystem C). Compared to BAU, projected total ecosystem $\mathrm{C}$ at the end of the century was $1 \%$ higher under the Low Harvest scenario, 6\% lower under Ecological Forestry, and 14\% lower under Accelerated Harvest. Soils contained the bulk of the $\mathrm{C}$ in the landscape, with nearly double the initial $\mathrm{C}$ as contained in aboveground biomass. Soils remained the largest $\mathrm{C}$ reservoir throughout the simulations, even under BAU and Low Harvest, where projected aboveground $\mathrm{C}$ substantially increased over time. Simulated timber volume across the region was similar under BAU, Low Harvest, and Ecological Forestry (average 61.3, 58.9, $58.8 \mathrm{~m}^{3} /$ ha, respectively, per $10-\mathrm{yr}$ time step) and substantially higher under Accelerated Harvest (average $76.1 \mathrm{~m}^{3} / \mathrm{ha}$; Fig. $4 \mathrm{~d}$ ). Note that while the Ecological Forestry scenario increased timber harvest on public lands, it reduced harvest on private lands, resulting in an overall similar level of harvest region wide. Timber volume varied temporally, which reflected the initial stand composition and the proportion of the landscape in each time step that contained stands eligible for harvest. The area occupied by old forest started out at $\sim 9 \%$ of the whole Coast Range landscape and increased to roughly $16 \%$ of the Coast Range landscape under BAU, Low Harvest, and Accelerated Harvest over the course of the century (Fig. 4e). Under Ecological Forestry, old forest accumulated more slowly, up to $13 \%$ of the Coast Range landscape over the course of the century.
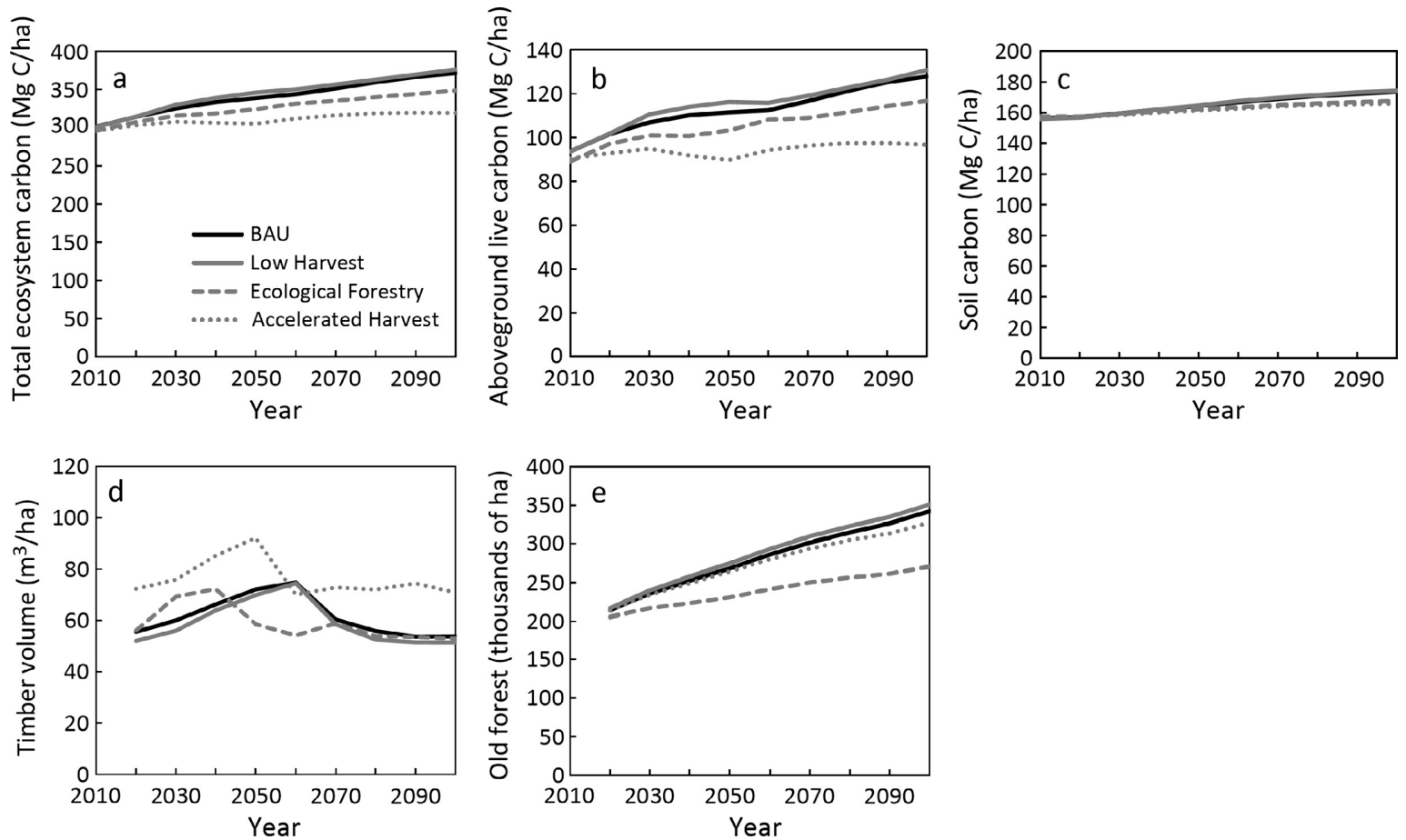

FIG. 4. Projections of ecosystem C, timber harvest, and old forest over time under four alternative management scenarios and contemporary climate. (a) Total ecosystem C is further divided into (b) aboveground live C, and (c) soil C. (d) Harvested timber shows average timber volume harvested per hectare (per 10-yr time step) and (e) area in old forest depicts the number of hectares of forest with maximum cohort age $>200$ yr old that is undisturbed by harvest. 
Spatial depictions of current and future projected aboveground $\mathrm{C}$ highlight the divergence of management between public and private lands under the BAU scenario (Fig. 5a). Current spatial patterns of aboveground live $\mathrm{C}$ are heterogeneous due to the NWFP and other protections on older forest habitat on public lands (Fig. 5b). This divide between private lands containing young plantations with low $\mathrm{C}$ and old forest containing high $\mathrm{C}$ on public lands became even more pronounced over simulated time (Fig. 5c). Spatial patterns of projections under the other management scenarios are not shown, but reflect similar patterns, as private lands are optimized for timber production and federal lands continue to retain much of the old forest area under all management scenarios.

\section{Forest management on federal lands}

Projections for federal lands (BLM and U.S. Forest Service) highlight trade-offs among C, timber, old forest, and natural early-seral forest habitat. As in the broader Coast Range landscape (across all ownerships), projections under the BAU and Low Harvest scenarios on federal lands were very similar, as BAU harvest levels were already low and declining over time. These scenarios projected high $\mathrm{C}$ and old forest accumulation, continually declining timber volume, and declining early-seral habitat (Fig. 6a-d). Under the Accelerated Harvest scenario, timber volume more than doubled, aboveground live $\mathrm{C}$ accumulation was $17 \%$ lower, and old forest was similar compared to BAU, with the increased harvesting occurring in young and mid-seral forest $<200 \mathrm{yr}$ old. Early-seral forest under Accelerated Harvest was very rare, and nearly indistinguishable from BAU. Under the Ecological Forestry scenario, aboveground $\mathrm{C}$ accumulation was $6 \%$ lower than BAU, timber volume was maintained at the current rate instead of declining over time, and old forest accumulation was $10 \%$ lower than BAU. In addition, native, early-seral forest, containing young trees and shrubs that naturally regenerated without planting, increased by 16-fold under Ecological Forestry, up from only 3000 ha under BAU to 55000 ha under Ecological Forestry.

\section{Climate change impacts}

All climate change scenarios increased forest productivity and $\mathrm{C}$ storage relative to historic climate under the BAU scenario. Total ecosystem $\mathrm{C}$ increased by $41-57 \mathrm{Mg} \mathrm{C} / \mathrm{ha}$ (11-15\%), with aboveground live $\mathrm{C}$ increasing

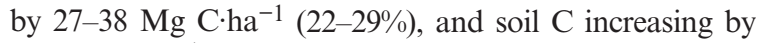
5-7 $\mathrm{Mg} \mathrm{C} \cdot \mathrm{ha}^{-1}(3-4 \%)$ relative to contemporary climate, by the end of the century (Fig. 7). These increases were primarily due to higher productivity in winter and spring months as temperature became less limiting (Table 3). Productivity declined slightly in summer months under climate change, but the increases in the other seasons far outweighed the summer decline. All climate change scenarios brought an increase in productivity, with the magnitude of change varying from an increase of $1.8 \mathrm{MgC} \cdot \mathrm{ha}^{-1} \cdot \mathrm{yr}^{-1}(30 \%)$ under
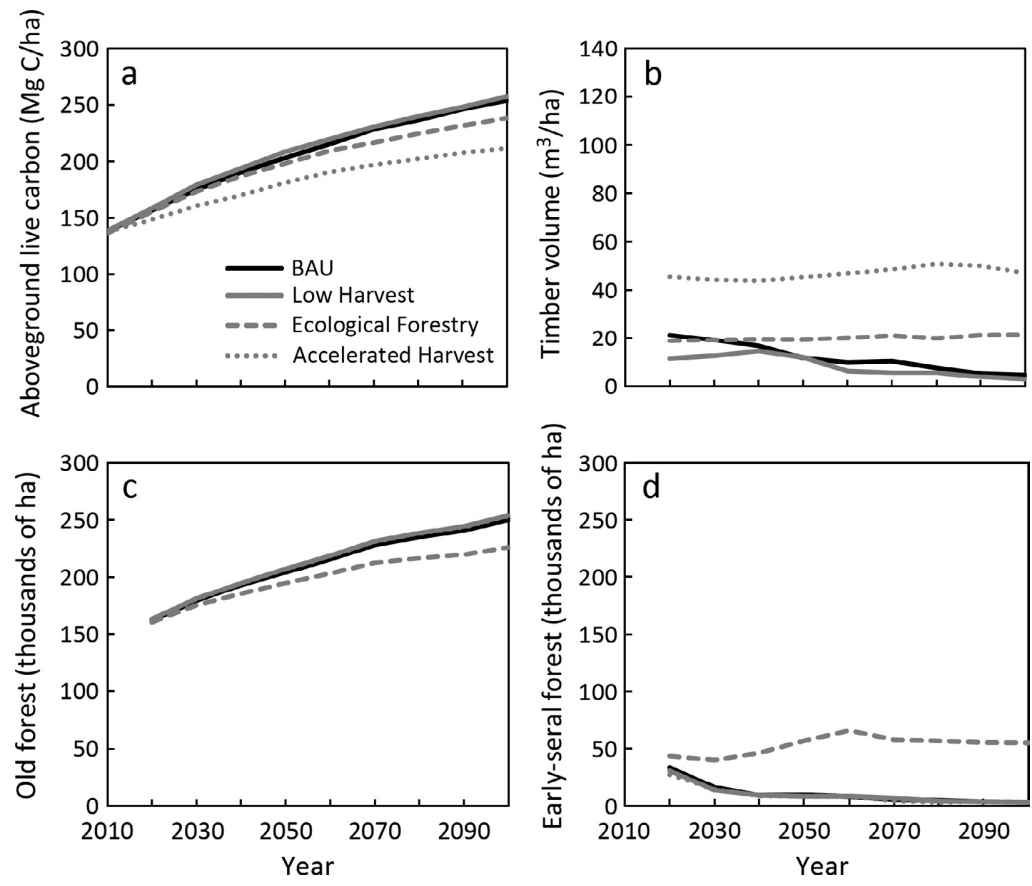

FIG. 5. For federal lands only, projections of (a) aboveground live C, (b) timber volume (per 10-yr time step), (c) area of old forest (area with maximum cohort age $>200 \mathrm{yr}$ old that is undisturbed by harvest), (d) and natural early-seral forest (area with maximum cohort age $<50 \mathrm{yr}$ old and not planted following harvest), under four management scenarios and contemporary climate. 


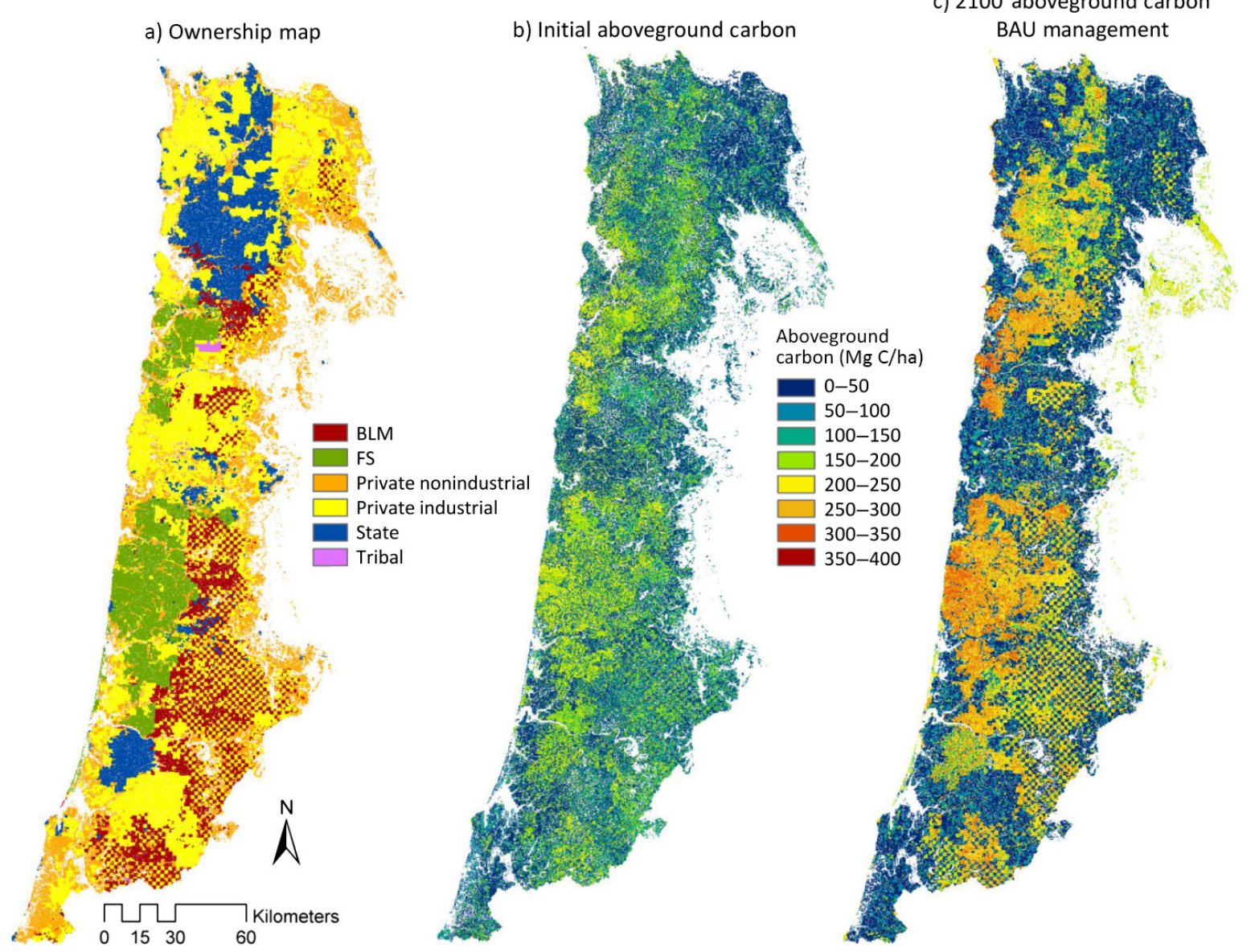

FIG. 6. (a) Spatial configuration of ownerships and (b) projected aboveground $\mathrm{C}(\mathrm{Mg} \mathrm{C} / \mathrm{ha})$ at the initiation of the simulation and (c) after 90 years under the BAU management scenario. Note the color ramp is the same for (b) and (c) to facilitate comparison of the two maps. BLM, U.S. Bureau of Land Management; FS, U.S. Forest Service. [Colour figure can be viewed at wileyonlinelibrary. com]

MRI to $2.5 \mathrm{Mg} \mathrm{C} \cdot \mathrm{ha}^{-1} \cdot \mathrm{yr}^{-1}(41 \%)$ under CCSM. Soil C accumulation also accelerated slightly with climate change due to the large increase in aboveground production (Fig. 7). Soil $\mathrm{C}$ inputs were partially offset by $\mathrm{C}$ losses due to increasing heterotrophic respiration with higher temperatures late in the century $\left(0.5-1.6 \mathrm{Mg} \mathrm{C} \cdot \mathrm{ha}^{-1} \cdot \mathrm{yr}^{-1}\right)$, but the gains in productivity exceeded respiration losses.

Under our climate projections, average FWI (a metric of fire weather, fuel moisture, and fire behavior index) of simulated wildfire events increased from 26.8 early in the century to 29.1 by the end of the century, and the number of wildfires that occurred under a FWI $>33$ increased from an average of 2.5 fires/yr early in the century to 3.5 fires/yr at the end of the century. As FWI increases, rate of spread (ROS) and mortality increase, and a faster ROS allows more area to burn. However, ROS was also constrained by our calibration to fire occurrence data from the last several decades, which includes suppression effects. Despite the increase in FWI over the century, projected area burned did not change consistently, with an average of 475 and 507 ha burned in early century (2011-2040) and late century
(2071-2100), respectively, under contemporary climatic conditions. Climate change projections did not differ substantially from contemporary conditions, with an average of 548 ha burned early century and 604 ha burned late in the century. Fire severity increased over the century in all climate scenarios, with contemporary climate increasing from 2.6 to 2.7 over the century, and climate change projections increasing from 2.6 to 2.9 over the course of the century. Larger individual wildfires occurred rarely under all climate scenarios, with an average of 2.8 fires $>2000$ ha and 0.9 fires $>5000$ ha over the 90 -year simulation.

\section{DisCUSSION}

\section{Cumulative impacts of management across the Coast Range landscape}

Our results suggest that shifting away from current timber management practices could substantially decrease ecosystem C storage. The BAU and Low Harvest scenarios stored the largest amount of ecosystem $C$, with up 

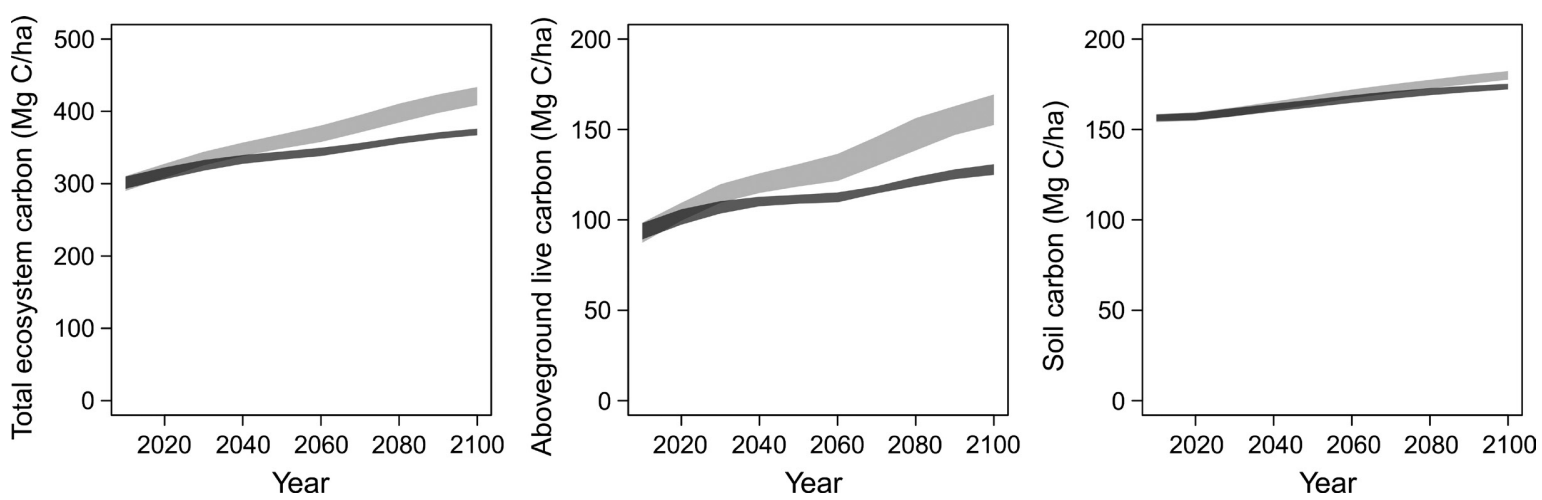

FIG. 7. C pools under contemporary climate and climate change. Dark-shaded envelope shows contemporary climate (mean \pm 1 $\mathrm{SD})$ and light-shaded envelope shows results under five climate change scenarios (mean $\pm 1 \mathrm{SD}$ ).

to $\sim 105 \mathrm{Tg}$ more $\mathrm{C}$ than the alternative scenarios across the whole landscape. Similarly, the difference among management scenarios in total $\mathrm{C}$ harvested over the simulation was over $70 \mathrm{Tg} \mathrm{C}$. For comparison purposes, the Biscuit Fire of 2002, which was one of the largest fires recorded in the state of Oregon, released an estimated 3.5-4.4 Tg C (Campbell et al. 2007). If we had considered more aggressive harvesting or conservation scenarios the magnitude of the change would be even greater; our results illustrate the magnitude of the impacts of management and policy on ecosystem $\mathrm{C}$.

The trade-offs with timber and old forest under BAU and Low Harvest were fairly obvious, with lower harvest levels leading to greater $\mathrm{C}$ storage and area occupied by old forest. These trade-offs, however, are less clear in the case of the other alternative scenarios. For instance, in the Accelerated Harvest scenario, timber volume increased by $25 \%$, but projected ecosystem $\mathrm{C}$ storage was only $14 \%$ lower, relative to BAU, by the end of the century. It wasn't surprising that there wasn't a 1:1 correspondence between harvest and $\mathrm{C}$ storage, since harvest primarily affects aboveground $\mathrm{C}$ storage but a large portion of the ecosystem $\mathrm{C}$ is stored belowground in soils. Soils are a relatively resilient $\mathrm{C}$ reservoir, continuing to accumulate $\mathrm{C}$ over time under all management scenarios (although accumulation slowed slightly with increased harvesting levels). The increase in harvest in the Accelerated Harvest scenario also had little effect on the extent of old forest because the increase in harvest was targeted in young and mature stands, with no harvesting in stands $>200$ yr old. Under the Ecological Forestry scenario, we see lower overall levels of timber harvest and intermediate impacts on ecosystem $\mathrm{C}$; however, old forest accumulated much more slowly under this scenario. The Ecological Forestry scenario left less intact old forest habitat because harvest was distributed more widely, with small patch cuts distributed across larger stands. This left less undisturbed old forest relative to the other scenarios but also left many remnant patches, minimized large clearcuts, and allowed natural early-seral habitat to regenerate on federal lands (see Forest management on federal lands).

Currently, C stocks on public lands are diverging markedly from private industrial forests in the Coast Range, with the former retaining high levels of ecosystem C and old forest, and the latter supplying the vast majority of timber. Not surprisingly, projecting current practices (BAU) forward to the end of the century magnified this pattern: federal lands accumulated higher $\mathrm{C}$ stocks and old forest, young plantations were maintained on private lands, and state lands were often intermediate between the two. This increase in spatial heterogeneity occurred

TABLE 3. Aboveground net primary productivity for each climate scenario by season and annual totals, averaged over the decades 1950-2009 for contemporary climate and 2080-2100 for future climate projections.

\begin{tabular}{|c|c|c|c|c|c|}
\hline \multirow[b]{2}{*}{ Climate scenario } & \multicolumn{5}{|c|}{ Aboveground net primary productivity $\left(\mathrm{Mg} \mathrm{C} / \mathrm{ha} \cdot \mathrm{yr}^{-1}\right)$} \\
\hline & Spring & Summer & Fall & Winter & Annual \\
\hline \multicolumn{6}{|l|}{ Contemporary } \\
\hline $1950-2009$ & 1.67 & 2.46 & 1.62 & 0.32 & 6.06 \\
\hline \multicolumn{6}{|l|}{ Future } \\
\hline BNU (2080-2100) & 2.72 & 2.00 & 1.96 & 1.73 & 8.41 \\
\hline CanESM (2080-2100) & 2.68 & 1.99 & 2.15 & 1.42 & 8.24 \\
\hline CCSM $(2080-2100)$ & 2.58 & 2.06 & 2.10 & 1.79 & 8.53 \\
\hline MRI (2080-2100) & 2.46 & 2.22 & 2.12 & 1.08 & 7.89 \\
\hline NorESM (2080-2100) & 2.63 & 1.96 & 2.12 & 1.64 & 8.35 \\
\hline
\end{tabular}

Note: Seasons are defined as spring (March-May), summer (June-August), fall (September-November), and winter (DecemberFebruary). 
under all management scenarios considered here, because we tailored each management scenario to the management intent of each combination of ownership type and management allocation. Therefore we captured the variation in spatial patterns due to ownership and constraints on land use within ownership types (e.g., wilderness areas and late-successional reserve status). In some areas, such as the Siuslaw National Forest, projections show large blocks of contiguous older forest. In other areas, such as BLM-administered lands interspersed with private lands in a checkerboard pattern, resulting forest age patterns will be highly fragmented (Chen et al. 1993, Mills 1995). These edges create a particular challenge for management (Blumm and Wigington 2013), with consequences for the connectivity of wildlife habitat (DellaSala et al. 2013).

\section{Forest management on federal lands}

All management scenarios considered here show a continued increase in $\mathrm{C}$ storage and old forest on federal lands. Projected timber volume under BAU and Low Harvest declined substantially over time because management is generally restricted to thinning of young stands with a maximum age cap, and stands become ineligible for any type of harvest as they age (Johnson et al. 2007). Notably, current implementation of the NWFP on federal lands (which we simulated here) is even more restrictive than mandated under the NWFP, as concerns about public perception and delays due to litigation have reduced harvesting by federal agencies on many lands (Keele et al. 2006, Thomas et al. 2006). As in the Coast Range-wide results, Accelerated Harvest produced more timber but did not cause a decline in old forest relative to BAU because the additional harvest was restricted to young and mature stands $<200 \mathrm{yr}$ old. Under the Ecological Forestry Scenario, harvest was used to increase the proportion of the landscape in natural earlyseral conditions. Natural early-seral forests are underrepresented in the current mix of forest ages in the Coast Range (Spies et al. 2007a), and contain a diverse array of early-seral species, including hardwood species such as red alder (Alnus rubra Bong.) and other shrubs that provide important habitat for many species (Ellis and Betts 2011, Swanson et al. 2011). In our simulations, these areas retained some large legacy trees and remnant patches during harvest and were not planted following harvest on federal lands, allowing early-seral species to colonize. The creation of early-seral habitat came at a cost to old forest in the simulations relative to BAU, but allowed sustained current levels of harvest (instead of a decline, as in BAU) and an increase over time in both natural early-seral and old forest habitat.

\section{Climate change impacts}

Our simulations suggest the forests of the Oregon Coast Range may be relatively resilient to climate change, with large increases in $\mathrm{C}$ storage due to higher productivity and low losses of $\mathrm{C}$ due to wildfire. The projected increase in total ecosystem C storage is largely due to increasing forest productivity under warmer temperatures in historically cool months, as expected for energylimited forests such as the Coast Range (McKenzie et al. 2001, Littell et al. 2010). The increases in productivity were most pronounced in winter months, with a 2.5- to 4.7-fold increase in productivity projected by the end of the century. Our simulations showed a decline in summer productivity due to water stress, as also found in several other studies (Littell et al. 2008, Chmura et al. 2011, Beedlow et al. 2013), but water stress in this relatively short window was less important than the projected increase in production during spring, winter, and fall months. Other modeling studies in the region have shown positive (Hudiburg et al. (2013), mixed (Rogers et al. 2011), and negative (Raymond and McKenzie 2012) effects of climate change on $\mathrm{C}$ in coastal Pacific Northwest forests. These disparate results highlight the differences among modeling approaches; for instance, LANDIS-II models growth and dispersal of individual species by age cohorts, whereas the MC1 model (Rogers et al. 2011) models changes in the potential distributions of broader plant functional types. The differences also reflect a lack of a complete understanding of all the physiological impacts of changing conditions on photosynthesis, growth, and phenology across forested ecosystems. For instance, LANDIS-II does not account for $\mathrm{CO}_{2}$ fertilization under climate change because the impacts of higher atmospheric $\mathrm{CO}_{2}$ are poorly understood at a species-specific level, but $\mathrm{MCl}$ includes $\mathrm{CO}_{2}$ fertilization because it is easier to generalize to plant functional types.

Our projections also indicated an increase in soil $\mathrm{C}$ under climate change, as inputs from highly productive vegetation exceed losses to heterotrophic respiration ( $\mathrm{Rh}$ ), despite elevated $\mathrm{Rh}$ with higher temperatures. Although there is some debate about the expected effects of increasing temperature on soil C stocks (Davidson and Janssen 2006, Schmidt et al. 2011, Bellassen and Luyssaert 2014), our results are consistent with a meta-analysis that found an increase in both soil respiration and plant productivity with warming (Rustad et al. 2001). Another related study in a single watershed within the Coast Range found a relatively small decrease in aboveground, soil and detrital $\mathrm{C}$ due to climate change (Creutzburg et al. 2015). The current study expanded to a broader region with greater overall precipitation (and thus lower summer water limitation), and incorporated improvements to the modeled soil water algorithms.

Although forests in coastal Oregon and Washington currently experience few wildfires, there is concern that climate change may lead to large, severe fires that could spread rapidly due to the abundance of fuels (Littell et al. 2010, Mote et al. 2014) and lower the ability of the Coast Range to store C. Climate is a primary driver of wildfire in the Pacific Northwest (Littell et al. 2009, 2010), and summer temperature is particularly important in 
determining wildfire activity (McKenzie et al. 2004, Littell et al. 2010). Although FWI and summer temperature increased in our climate change simulations, there was no consistent projected increase in area of forest burned with climate change. However, when wildfires did occur in simulations, there was an increase in their severity, leading to greater tree mortality in fire affected areas. Several other studies in the region projected increasing wildfire size with climate change, ranging from a projected doubling or tripling over the century (Littell et al. 2010), an increase of $150 \%$ to $1100 \%$ (Rogers et al. 2011), and a projected $400-500 \%$ increase in area burned with every degree of warming (Peterson and Littell 2012). However, these approaches did not account for management activities, which are extensive in the Coast Range landscape. More than $60 \%$ of the landscape is managed for short-rotation timber production, with a dense road network, heavy fire suppression efforts to prevent the loss of timber, and vegetation treatments to limit seedling competition from shrubs (and thus also limiting ground and ladder fuels). Other large fires in the region, such as the 2002 Biscuit Fire, which burned over 200000 ha immediately south of the Coast Range (Campbell et al. 2016), occurred in remote areas with very little fragmentation (Heilman et al. 2002). Many other comparable studies also consider broader ecoregions, in many cases including the Cascade Mountains, which contain much less fragmentation and active timber harvest (Rogers et al. 2011, Peterson and Littell 2012).

Fires currently affect $<0.1 \%$ of the Coast Range area per year, on average, and even an increase of several times still maintains wildfire as a relatively minor disturbance across the landscape. Landscapes that are intensively managed may experience less fire relative to pre-management conditions (Nowacki and Abrams 2008), and hence the need for disturbance emulation (Perera et al. 2007), regardless of climate change (Scheller et al. 2012, Loudermilk et al. 2013). Overall, our results suggest that it is unlikely that wildfire will cause substantial declines in C storage in the Coast Range, particularly given the expected increase in productivity with climate change. Our projections show a 87-121 Tg increase in ecosystem $\mathrm{C}$ storage with climate change by the end of the century, relative to contemporary climate, more than 20 times greater than the estimated 3.5-4.4 Tg C released from the Biscuit fire (Campbell et al. 2007), one of the largest fires in Oregon history.

\section{Limitations}

The management scenario results presented are not an endorsement of any management or policy option. We chose scenarios that highlight the landscape effects of variations in the amount and type of harvesting throughout the Coast Range, tailored to the widely varying ownerships and management types in the region. There are many other alternative management options that were not explored here; we chose to contrast current practices with three alternative scenarios based on stakeholder inputs. There are also many other ways of implementing each scenario, e.g., with different age restrictions and patch sizes. As a broad scale study, we omitted finescale management; for example, we did not simulate riparian management because linear riparian features are generally below the 4-ha cell resolution. Similarly, we could not simulate individual remnant trees and snags on a harvested site. Finally, urbanization and other types of land use will likely change in the region (Kline et al. 2001, Spies et al. 2007a), but here we assume the forested extent will remain constant.

Several additional limitations and caveats are important to note when interpreting our climate change projections. There is uncertainty in projections of temperature and precipitation under varying climate models (Knutti and Sedlacek 2013); however, we selected several climate change models representing varying conditions to capture much of the expected future range. Regardless, the confidence in our projections is highest in the short-term, with greatest uncertainty in projections late in the century. In addition, not all potential physiological effects of climate change were modeled, including winter chilling requirements and $\mathrm{CO}_{2}$ fertilization. Many conifer species require a period of winter chilling for normal bud burst and growth, and climate change may increase winter temperatures enough to affect bud-burst, flowering, and seed germination (Cumming and Burton 1996, Chmura et al. 2011). $\mathrm{CO}_{2}$ fertilization from anthropogenic greenhouse gas emissions is also likely to increase production under climate change due to increased photosynthetic rates and water use efficiency (Norby et al. 2005, Keenan et al. 2013). Additionally, the Century Succession extension does not incorporate photosynthetically active radiation (PAR) into the simulation of tree growth. The increase in productivity with climate change was a function of increasing winter temperatures; however, these increases may be overestimated due to shorter day lengths and lower PAR in winter months. Other weather conditions, such as the influence of the fog belt along the Pacific Coast (Franklin and Dyrness 1973), were also not represented in the LANDIS-II model. Finally, other disturbances, such as insects and disease, may also be altered by climate change and were not included in our simulations. For instance, Swiss Needle Cast, which reduces the growth of young Douglas-fir plantations due infection by the fungus Phaeocryptopus gaeumannii, has been increasing in severity in recent years (Black et al. 2010) and may be exacerbated with climate change (Stone et al. 2008).

Additionally our wildfire projections contain substantial uncertainty. They were constrained by calibration to the available data record, which was short in duration (44 years), contained relatively few ignitions per year due to the high rainfall in the region, and contained only one fire $>2000$ ha in size. Other studies have provided a longer-term perspective of pre-settlement wildfire in the Coast Range (Long et al. 1998, Wimberly et al. 2000, Wimberly 2002, Thompson et al. 2006), but our 
model calibration was limited to the recent time period with a continuous record of wildfire events, incorporating the effects of suppression. The potential for large fires in our simulations was also limited by the small number of ignitions that occur in the Coast Range, providing few opportunities to start a fire that could potentially grow to a large size. Extreme wildfire events are difficult to predict (McKenzie et al. 1996, Scheller et al. $2011 b$ ), and a greater number of simulations may be required to reveal significant patterns in large wildfire events. Fuel type categories were also relatively coarse, resulting in wildfire projections that reflect broad trends in fuels and weather but not spatially precise projections of fire behavior or risk.

\section{Conclusions}

To make informed decisions, policy makers, forest managers, and the general public require information regarding trade-offs, including both their existence and their magnitude, when evaluating forest management options in the face of climate change. Balancing multiple ecosystem services is challenging, particularly in the Pacific Northwest, where forest protection can conflict with timber harvesting. Among our management scenarios, maintaining $\mathrm{C}$ storage and old forest was best achieved using current (BAU) or similar (e.g., Low Harvest scenario) practices, but the Ecological Forestry scenario allowed an increase in both old forest and natural early-seral habitat. To increase timber harvesting, there will be trade-offs with ecosystem $\mathrm{C}$ and multiple types of habitat. The trade-off between timber harvest and ecosystem $C$ is currently playing out spatially across the landscape, with PIF lands increasingly divergent from state and federally managed lands; the former producing the majority of the timber, and latter sequestering more $\mathrm{C}$ and maintaining more old forest habitat. Our simulations also suggest these coastal forests are relatively resilient to climate change, with increasing cool-season productivity exceeding summer drought stress. There is also a large degree of "managed resilience" via fire suppression; large, infrequent wildfires will remain a risk, but landscape-level effects of wildfire on $\mathrm{C}$ storage are likely to be minimal. If productivity increases as projected, there may be potential for increasing timber harvest in some areas while maintaining ecosystem $\mathrm{C}$ in others. Soils are the largest $\mathrm{C}$ pool in the Coast Range, and demonstrate fairly high resilience to both climate change and management. Ultimately, choices on the provisioning of ecosystem services, deciding on the right mix of timber, $\mathrm{C}$ storage and habitat, are decided in the public arena. This approach to evaluating alternative scenarios can aid society in assessing the long-term trade-offs among ecosystem services and inform landscape-level policies.

\section{ACKNOWLEDGMents}

Funding was provided by the U.S. Bureau of Land Management and Environmental Protection Agency Interagency
Agreement DW-14-95829801-0. Thanks to George McFadden and Louisa Evers of the Bureau of Land Management, and Greg Johnson, David Marshall, and Scott Holub of Weyerhaeuser for their input. Many thanks to representatives from the Environmental Protection Agency, Bureau of Land Management, U.S. Forest Service, Oregon Department of Forestry, Grand Ronde tribe, Oregon Wild, Oregon State University, and others who attended the management scenario workshop and assisted in developing management scenarios. Thanks also to the Landscape Ecology, Modeling, Mapping, and Analysis team for providing vegetation maps and biomass estimates, and Steve Campbell of NRCS for assistance with soil data processing. Alec Kretchun and Lesley Bross provided instrumental programming support. Thanks to Peter Beedlow and Ellen Cooter of the U.S. Environmental Protection Agency, and reviewers for their feedback on earlier versions of this manuscript. The views expressed here are those of the authors and do not necessarily represent the views or policies of the U.S. Environmental Protection Agency or Bureau of Land Management.

\section{Literature Cited}

Allen, C. D., et al. 2010. A global overview of drought and heatinduced tree mortality reveals emerging climate change risks for forests. Forest Ecology and Management 259:660-684.

Bachelet, D., R. P. Neilson, J. M. Lenihan, and R. J. Drapek. 2001. Climate change effects on vegetation distribution and carbon budget in the United States. Ecosystems 4:164-185.

Beedlow, P. A., E. H. Lee, D. T. Tingey, R. S. Waschmann, and C. A. Burdick. 2013. The importance of seasonal temperature and moisture patterns on growth of Douglas-fir in western Oregon, USA. Agricultural and Forest Meteorology 169: 174-185.

Bellassen, V., and S. Luyssaert. 2014. Managing forests in uncertain times. Nature 506:153-155.

Black, B. A., D. C. Shaw, and J. K. Stone. 2010. Impacts of Swiss needle cast on overstory Douglas-fir forests of the western Oregon Coast Range. Forest Ecology and Management 259:1673-1680.

Blumm, M. C., and T. Wigington. 2013. The Oregon \& California railroad grant lands' sordid past, contentious present, and uncertain future: a century of conflict. Environmental Affairs 40:1-76.

Bonan, G. B. 2008. Forests and climate change: forcings, feedbacks, and the climate benefits of forests. Science 320: 1444-1449.

Brekke, L., B. Thrasher, E. Maurer, and T. Pruitt. 2013. Downscaled CMIP3 and CMIP5 climate projections: release of downscaled CMIP5 climate projections, comparison with preceding Information, and summary of user needs. Prepared by the U.S. Department of the Interior, Bureau of Reclamation, Technical Services Center, Denver, Colorado, USA

Briggs, D. 2007. Management practices on Pacific Northwest west-side industrial forest lands, 1991-2005: with projections to 2010. Page 84 in Stand Management Cooperative Working Paper Number 6. College of Forest Resources, University of Washington, Seattle, Washington, USA.

Butler, B. J., J. J. Swenson, and R. J. Alig. 2004. Forest fragmentation in the Pacific Northwest: quantification and correlations. Forest Ecology and Management 189:363-373.

Campbell, J., D. C. Donato, D. Azuma, and B. Law. 2007. Pyrogenic carbon emission from a large wildfire in Oregon, United States. Journal of Geophysical ResearchBiogeosciences 112:GO40 14.

Campbell, J. L., J. B. Fontaine, and D. C. Donato. 2016. Carbon emissions from decomposition of fire-killed trees 
following a large wildfire in Oregon, United States. Journal of Geophysical Research: Biogeosciences 121:718-730.

Chen, J. Q., J. F. Franklin, and T. A. Spies. 1993. Contrasting microclimates among clearcut, edge, and interior of oldgrowth Douglas-fir forest. Agricultural and Forest Meteorology 63:219-237.

Chmura, D. J., P. D. Anderson, G. T. Howe, C. A. Harrington, J. E. Halofsky, D. L. Peterson, D. C. Shaw, and J. B. St Clair. 2011. Forest responses to climate change in the northwestern United States: ecophysiological foundations for adaptive management. Forest Ecology and Management 261:1121-1142.

Coops, N. C., and R. H. Waring. 2011. Estimating the vulnerability of fifteen tree species under changing climate in Northwest North America. Ecological Modelling 222:2119-2129.

Creutzburg, M. K., R. M. Scheller, M. S. Lucash, L. B. Evers, S. D. LeDuc, and M. G. Johnson. 2015. Bioenergy harvest, climate change, and forest carbon in the Oregon Coast Range. Global Change Biology Bioenergy. http://dx.doi. org/10.1111/gcbb. 12255

Cumming, S. G., and P. J. Burton. 1996. Phenology-mediated effects of climatic change on some simulated British Columbia forests. Climatic Change 34:213-222.

Dale, V. H., et al. 2001. Climate change and forest disturbances. BioScience 51:723-734.

Daly, C., G. H. Taylor, and W. P. Gibson. 1997. The PRISM approach to mapping precipitation and temperature. Pages 10-12 in Proceedings of the 10th American Meteorological Society Conference on Applied Climatology. American Meteorological Society, Reno, Nevada, USA.

D'Amato, A. W., J. B. Bradford, S. Fraver, and B. J. Palik. 2011. Forest management for mitigation and adaptation to climate change: insights from long-term silviculture experiments. Forest Ecology and Management 262:803-816.

Davidson, E. A., and I. A. Janssen. 2006. Temperature sensitivity of soil carbon decomposition and feedbacks to climate change. Nature 440:165-173.

DellaSala, D. A., R. G. Anthony, M. L. Bond, E. S. Fernandez, C. A. Frissell, C. T. Hanson, and R. Spivak. 2013. Alternative views of a restoration framework for federal forests in the Pacific Northwest. Journal of Forestry 111:420-429.

Duveneck, M. J., R. M. Scheller, M. A. White, S. D. Handler, and C. Ravenscroft. 2014. Climate change effects on northern Great Lake (USA) forests: a case for preserving diversity. Ecosphere 5:1-26.

Ellis, T. M., and M. G. Betts. 2011. Bird abundance and diversity across a hardwood gradient within early seral plantation forest. Forest Ecology and Management 261:1372-1381.

Fenn, M. E., et al. 2003. Nitrogen emissions, deposition, and monitoring in the western United States. BioScience 53:391-403.

Finney, M. A. 2002. Fire growth using minimum travel time methods. Canadian Journal of Forest Research 32:1420-1424.

Forestry Canada Forest Fire Danger Fire Danger Group. 1992. Development and Structure of the Canadian Forest Fire Behavior Prediction System. Information Report ST-X-3, Forestry Canada, Quebec, Canada.

Franklin, J. F., and C. T. Dyrness. 1973. Natural vegetation of Oregon and Washington. USDA Forest Service General Technical Report PNW-8. U.S. Department of Agriculture, Pacific Northwest Forest and Range Experiment Station, Portland, Oregon, USA.

Franklin, J. F., and K. N. Johnson. 2012. A restoration framework for federal forests in the Pacific Northwest. Journal of Forestry 110:429-439.

Franklin, J. F., et al. 2002. Disturbances and structural development of natural forest ecosystems with silvicultural implications, using Douglas-fir forests as an example. Forest Ecology and Management 155:399-423.

Golden, D. M., M. A. Smith, and S. J. Colombo. 2011. Forest carbon management and carbon trading: a review of Canadian forest options for climate change mitigation. Forestry Chronicle 87:625-635.

Hansen, A. J., W. C. Mccomb, R. Vega, M. G. Raphael, and M. Hunter. 1995. Bird habitat relationships in natural and managed forests in the west Cascades of Oregon. Ecological Applications 5:555-569.

Heilman, G. E., J. R. Strittholt, N. C. Slosser, and D. A. Dellasala. 2002. Forest fragmentation of the conterminous United States: assessing forest intactness through road density and spatial characteristics. BioScience 52:411-422.

Hein, L., K. van Koppen, R. S. de Groot, and E. C. van Ierland. 2006. Spatial scales, stakeholders and the valuation of ecosystem services. Ecological Economics 57:209-228.

Hudiburg, T. W., S. Luyssaert, P. E. Thornton, and B. E. Law. 2013. Interactive effects of environmental change and management strategies on regional forest carbon emissions. Environmental Science \& Technology 47:13132-13140.

Johnson, D. W., D. W. Cole, C. S. Bledsoe, K. Cromack, R. L. Edmonds, S. P. Gessel, C. C. Grier, B. N. Richards, and K. A. Vogt. 1982. Chapter 7: Nutrient cycling in forests of the Pacific Northwest. Pages 186-232 in R. L. Edmonds, editor. Analysis of coniferous forest ecosystems in the western United States. Hutchinson Ross Publishing Company, Stroudsburg, Pennsylvania, USA.

Johnson, K. N., P. Bettinger, J. D. Kline, T. A. Spies, M. Lennette, G. Lettman, B. Garber-Yonts, and T. Larsen. 2007. Simulating forest structure, timber production, and socioeconomic effects in a multi-owner province. Ecological Applications 17:34-47.

Johnson, R., R. Alig, J. Kline, R. Moulton, and M. Rickenbach. 1999. Management of non-industrial private forest lands: survey results from western Oregon and Washington owners. Research Contribution 28, Forest Research Laboratory, Oregon State University, Corvallis, Oregon, USA.

Keele, D. M., R. W. Malmsheimer, D. W. Floyd, and J. E. Perez. 2006. Forest service land management litigation 19892002. Journal of Forestry 104:196-202.

Keenan, T. F., D. Y. Hollinger, G. Bohrer, D. Dragoni, J. W. Munger, H. P. Schmid, and A. D. Richardson. 2013. Increase in forest water-use efficiency as atmospheric carbon dioxide concentrations rise. Nature 499:324-327.

Kennedy, R. S. H., and T. A. Spies. 2004. Forest cover changes in the Oregon Coast Range from 1939 to 1993. Forest Ecology and Management 200:129-147.

Kline, J. D., A. Moses, and R. J. Alig. 2001. Integrating urbanization into landscape-level ecological assessments. Ecosystems 4:3-18.

Knutti, R., and J. Sedlacek. 2013. Robustness and uncertainties in the new CMIP5 climate model projections. Nature Climate Change 3:369-373.

Kurz, W. A., C. C. Dymond, G. Stinson, G. J. Rampley, E. T. Neilson, A. L. Carroll, T. Ebata, and L. Safranyik. 2008. Mountain pine beetle and forest carbon feedback to climate change. Nature 452:987-990.

Littell, J. S., D. McKenzie, D. L. Peterson, and A. L. Westerling. 2009. Climate and wildfire area burned in western U. S. ecoprovinces, 1916-2003. Ecological Applications 19:1003-1021.

Littell, J. S., E. E. Oneil, D. McKenzie, J. A. Hicke, J. A. Lutz, R. A. Norheim, and M. M. Elsner. 2010. Forest ecosystems, disturbance, and climatic change in Washington State, USA. Climatic Change 102:129-158. 
Littell, J. S., D. L. Peterson, and M. Tjoelker. 2008. Douglas-fir growth in mountain ecosystems: water limits tree growth from stand to region. Ecological Monographs 78:349-368.

Long, C. J., C. Whitlock, P. J. Bartlein, and S. H. Millspaugh. 1998. A 9000-year fire history from the Oregon Coast Range, based on a high-resolution charcoal study. Canadian Journal of Forest Research 28:774-787.

Loudermilk, E. L., R. M. Scheller, P. J. Weisberg, J. Yang, T. E. Dilts, S. L. Karam, and C. Skinner. 2013. Carbon dynamics in the future forest: the importance of long-term successional legacy and climate-fire interactions. Global Change Biology 19:3502-3515.

Lu, M., X. H. Zhou, Q. Yang, H. Li, Y. Q. Luo, C. M. Fang, J. K. Chen, X. Yang, and B. Li. 2013. Responses of ecosystem carbon cycle to experimental warming: a meta-analysis. Ecology 94:726-738.

Lucash, M. S., and R. M. Scheller. 2015. LANDIS-II climate library v1 user guide. Portland State University, Portland, Oregon, USA.

Maurer, E. P., A. W. Wood, J. C. Adam, D. P. Lettenmaier, and B. Nijssen. 2002. A long-term hydrologically based dataset of land surface fluxes and states for the conterminous United States. Journal of Climate 15:3237-3251.

McKenzie, D., Z. Gedalof, D. L. Peterson, and P. Mote. 2004. Climatic change, wildfire, and conservation. Conservation Biology 18:890-902.

McKenzie, D., A. E. Hessl, and D. L. Peterson. 2001. Recent growth of conifer species of western North America: assessing spatial patterns of radial growth trends. Canadian Journal of Forest Research 31:526-538.

McKenzie, D., D. L. Peterson, and E. Alvarado. 1996. Extrapolation problems in modeling fire effects at large spatial scales: a review. International Journal of Wildland Fire 6:165-176.

McKinley, D. C., et al. 2011. A synthesis of current knowledge on forests and carbon storage in the United States. Ecological Applications 21:1902-1924.

Mills, L. S. 1995. Edge effects and isolation-red-backed voles on forest remnants. Conservation Biology 9:395-402.

Mote, P., A. K. Snover, S. Capalbo, S. D. Eigenbrode, P. Glick, J. Littell, R. Raymondi, and S. Reeder. 2014. Northwest. Chapter 21 in J. M. Melillo, T. C. Richmond, and G. W. Yohe, editors. Climate change impacts in the United States: the Third National Climate Assessment. U.S. Global Change Research Program, Washington, D.C., USA.

Norby, R. J., et al. 2005. Forest response to elevated $\mathrm{CO}_{2}$ is conserved across a broad range of productivity. Proceedings of the National Academy of Sciences USA 102:18052-18056.

Nowacki, G. J., and M. D. Abrams. 2008. The demise of fire and "mesophication" of forests in the eastern United States. BioScience 58:123-138.

Ohmann, J. L., and M. J. Gregory. 2002. Predictive mapping of forest composition and structure with direct gradient analysis and nearest-neighbor imputation in coastal Oregon, USA. Canadian Journal of Forest Research 32:725-741.

Pan, Y. D., et al. 2011. A large and persistent carbon sink in the world's forests. Science 333:988-993.

Parton, W. J., D. W. Anderson, C. V. Cole, and J. W. B. Steward. 1983. Simulation of soil organic matter formation and mineralization in semiarid agroecosystems. in R. R. Lowrance, R. L. Todd, L. E. Asmussen, and R. A. Leonard, editors. Special Publication No. 23. Nutrient cycling in agricultural ecosystems. The University of Georgia, College of Agriculture Experiment Stations, Athens, Georgia, USA.

Perakis, S. S., E. R. Sinkhorn, and J. E. Compton. 2011. delta $\mathrm{N}-15$ constraints on long-term nitrogen balances in temperate forests. Oecologia 167:793-807.
Perera, A. H., L. J. Buse, and M. G. Weber. 2007. Emulating natural forest landscape disturbances: concepts and applications. Columbia University Press, New York, New York, USA.

Peterson, D. L., and J. S. Littell. 2012. Risk assessment for wildfire in the western United States. Pages 249-252 in J. M. Vose, D. L. Peterson, and T. Patel-Weynand, editors. Effects of climatic variability and change on forest ecosystems: a comprehensive science synthesis for the U.S. forest sector. General Technical Report PNW-GTR-870. U.S. Department of Agriculture, Forest Service, Pacific Northwest Research Station, Portland, Oregon, USA.

Phelps, J., D. A. Friess, and E. L. Webb. 2012. Win-win REDD+ approaches belie carbon-biodiversity trade-offs. Biological Conservation 154:53-60.

Pong, W. Y., D. R. WaddelI, and M. B. Lambert. 1986. Wood density-moisture profiles in old-growth Douglas-fir and western hemlock. Research Paper PNW-347. US Department of Agriculture, Forest Service, Pacific Northwest Research Station, Portland, Oregon, USA.

Power, T. M. 2006. Public timber supply, market adjustments, and local economies: economic assumptions of the northwest forest plan. Conservation Biology 20:341-350.

Raymond, C. L., and D. McKenzie. 2012. Carbon dynamics of forests in Washington, USA: 21st century projections based on climate-driven changes in fire regimes. Ecological Applications 22:1589-1611.

Rehfeldt, G. E., N. L. Crookston, M. V. Warwell, and J. S. Evans. 2006. Empirical analyses of plant-climate relationships for the western United States. International Journal of Plant Sciences 167:1123-1150.

Rogers, B. M., R. P. Neilson, R. Drapek, J. M. Lenihan, J. R. Wells, D. Bachelet, and B. E. Law. 2011. Impacts of climate change on fire regimes and carbon stocks of the U.S. Pacific Northwest. Journal of Geophysical Research: Biogeosciences 116:G03037.

Rustad, L. E., J. L. Campbell, G. M. Marion, R. J. Norby, M. J. Mitchell, A. E. Hartley, J. H. C. Cornelissen, J. Gurevitch, and Gcte-News. 2001. A meta-analysis of the response of soil respiration, net nitrogen mineralization, and aboveground plant growth to experimental ecosystem warming. Oecologia 126:543-562.

Scheller, R. M., J. B. Domingo, B. R. Sturtevant, J. S. Williams, A. Rudy, E. J. Gustafson, and D. J. Mladenoff. 2007. Design, development, and application of LANDIS-II, a spatial landscape simulation model with flexible spatial and temporal resolution. Ecological Modelling 201:409-419.

Scheller, R. M., D. Hua, P. V. Bolstad, R. A. Birdsey, and D. J. Mladenoff. 2011a. The effects of forest harvest intensity in combination with wind disturbance on carbon dynamics in Lake States mesic forests. Ecological Modelling 222: 144-153.

Scheller, R. M., A. M. Kretchun, S. Van Tuyl, K. L. Clark, M. S. Lucash, and J. Hom. 2012. Divergent carbon dynamics under climate change in forests with diverse soils, tree species, and land use histories. Ecosphere 3:1-16.

Scheller, R. M., and D. J. Mladenoff. 2004. A forest growth and biomass module for a landscape simulation model, LANDIS: design, validation, and application. Ecological Modelling 180:211-229.

Scheller, R. M., W. D. Spencer, H. Rustigian-Romsos, A. D. Syphard, B. C. Ward, and J. R. Strittholt. 2011b. Using stochastic simulation to evaluate competing risks of wildfires and fuels management on an isolated forest carnivore. Landscape Ecology 26:1491-1504.

Scheller, R. M., S. Van Tuyl, K. L. Clark, J. Hom, and I. La Puma. 2011c. Carbon sequestration in the New Jersey pine 
barrens under different scenarios of fire management. Ecosystems 14:987-1004.

Schmidt, M. W. I., et al. 2011. Persistence of soil organic matter as an ecosystem property. Nature 478:49-56.

Seidl, R., W. Rammer, D. Jager, W. S. Currie, and M. J. Lexer. 2007. Assessing trade-offs between carbon sequestration and timber production within a framework of multi-purpose forestry in Austria. Forest Ecology and Management 248:64-79.

Smithwick, E. A. H., M. E. Harmon, S. M. Remillard, S. A. Acker, and J. F. Franklin. 2002. Potential upper bounds of carbon stores in forests of the Pacific Northwest. Ecological Applications 12:1303-1317.

Sollins, P., C. C. Grier, F. M. Mccorison, K. Cromack, and R. Fogel. 1980. The internal element cycles of an old-growth Douglas-fir ecosystem in western Oregon. Ecological Monographs 50:261-285.

Spies, T. A., K. N. Johnson, K. M. Burnett, J. L. Ohmann, B. C. McComb, G. H. Reeves, P. Bettinger, J. D. Kline, and B. Garber-Yonts. 2007a. Cumulative ecological and socioeconomic effects of forest policies in Coastal Oregon. Ecological Applications 17:5-17.

Spies, T. A., B. C. McComb, R. S. H. Kennedy, M. T. Mcgrath, K. Olsen, and R. J. Pabst. 2007b. Potential effects of forest policies on terrestrial biodiversity in a multi-ownership province. Ecological Applications 17:48-65.

Stavros, E. N., J. T. Abatzoglou, D. McKenzie, and N. K. Larkin. 2014. Regional projections of the likelihood of very large wildland fires under a changing climate in the contiguous western United States. Climatic Change 126:455-468.

Stone, J. K., L. B. Coop, and D. K. Manter. 2008. Predicting effects of climate change on Swiss needle cast disease severity in Pacific Northwest forests. Canadian Journal of Plant Pathology 30:169-176.

Sturtevant, B. R., R. M. Scheller, B. R. Miranda, and D. Shinneman. 2009. Simulating dynamic and mixed-severity fire regimes: a process-based fire extension for LANDIS-II. Ecological Modeling 220:3380-3393.

Swallow, S. K., P. Talukdar, and D. N. Wear. 1997. Spatial and temporal specialization in forest ecosystem management under sole ownership. American Journal of Agricultural Economics 79:311-326.

Swanson, M. E., J. F. Franklin, R. L. Beschta, C. M. Crisafulli, D. A. DellaSala, R. L. Hutto, D. B. Lindenmayer, and F. J.
Swanson. 2011. The forgotten stage of forest succession: early-successional ecosystems on forest sites. Frontiers in Ecology and the Environment 9:117-125.

Syphard, A. D., R. M. Scheller, B. C. Ward, W. D. Spencer, and J. R. Strittholt. 2011. Simulating landscape-scale effects of fuels treatments in the Sierra Nevada, California. International Journal of Fire Management 20:364-383.

Thomas, J. W., J. F. Franklin, J. Gordon, and K. N. Johnson. 2006. The northwest forest plan: origins, components, implementation experience, and suggestions for change. Conservation Biology 20:277-287.

Thompson, J. R., K. N. Johnson, M. Lennette, T. A. Spies, and P. Bettinger. 2006. Historical disturbance regimes as a reference for forest policy in a multiowner province: a simulation experiment. Canadian Journal of Forest Research 36:401-417.

Thornley, J. H. M., and M. G. R. Cannell. 2000. Managing forests for wood yield and carbon storage: a theoretical study. Tree Physiology 20:477-484.

Westerling, A. L., H. G. Hidalgo, D. R. Cayan, and T. W. Swetnam. 2006. Warming and earlier spring increase western US forest wildfire activity. Science 313:940-943.

Wheeler, A. 2012. Case study: Roseburg district pilot project. Journal of Forestry 110:439-441.

Wimberly, M. C. 2002. Spatial simulation of historical landscape patterns in coastal forests of the Pacific Northwest. Canadian Journal of Forest Research 32:1316-1328.

Wimberly, M. C., T. A. Spies, C. J. Long, and C. Whitlock. 2000. Simulating historical variability in the amount of old forests in the Oregon Coast Range. Conservation Biology 14:167-180.

Yang, J., H. S. He, and E. J. Gustafson. 2004. A hierarchical fire frequency model to simulate temporal patterns of fire regimes in LANDIS. Ecological Modelling 180:119-134.

Zhang, L., D. J. Jacob, E. M. Knipping, N. Kumar, J. W. Munger, C. C. Carouge, A. van Donkelaar, Y. X. Wang, and D. Chen. 2012. Nitrogen deposition to the United States: distribution, sources, and processes. Atmospheric Chemistry and Physics 12:4539-4554.

Zhou, X., and M. A. Hemstrom. 2009. Estimating aboveground tree biomass on forest land in the Pacific Northwest. Research Paper PNW-RP-584. U.S. Department of Agriculture, Forest Service, Pacific Northwest Research Station, Portland, Oregon, USA.

\section{SUPPORTING INFORMATION}

Additional supporting information may be found in the online version of this article at http://onlinelibrary.wiley.com/ doi/10.1002/eap.1460/full

\section{Data Avallability}

Data associated with this paper have deposited in the LANDIS-II Foundation website: https:/github.com/LANDIS-IIFoundation/Project-Oregon-Coast-Range 